Zusammenfassung. Durch Ausfeilung der Operationstechnik ist es in den letzten 2 Jahren gelungen, den Wiederaufbau einer Brust in 1-2 Operationsakten durchzuführen. Für den Ersatz der fehlenden Haut, des fehlenden Drüsen-, Fett- und Muskelgewebes sowie der Mamille mit Warzenhof steht der plastischen Chirurgie eine weite Palette von Möglichkeiten zur Verfügung, aus der je nach den Erfordernissen die eine oder andere Methode ausgewählt wird. Auch wurden in den letzten 2 Jahren die Ergebnisse so gut, daß nicht nur brustähnliche Gebilde, sondern wirklich weibliche Brüste entstanden. Dadurch wurde auch die Qualität der Überlebenszeit der Patientinnen verbessert.

Schlüsselwörter: Rekonstruktion der Brust - Mastektomie, radikale - Mamma-Carcinom - Brustwarzenrekonstruktion.

\title{
114. Erste Erfahrungen mit der Zipfelplastik bei der Korrektur der Oesophagusatresie vom Typ IIIb
}

\author{
E. Müller \\ Chirurg. Univ.-Klinik A, Moorenstr. 5, D-4000 Düsseldorf
}

\section{First Experiences with the Triangular Flap Graft in Correction of a Type-IIIb Atresia of the Esophagus}

Summary. After correction of type-IIIb atresia of the esophagus the incidence of postoperative anastomotic stenosis is approximately 15 to 40 percent. Since 1974 , a new method the triangular flap graft (according to Gütgemann and others), has been used for anastomosing the esophagus in cases of atresia of this type. Its advantages are that circular anastomoses are avoided and tensions are shifted to a sloping plane. Results: 10 of 14 patients subjected to surgery survived. In 8 cases progress was smooth without stenosis, in 1 case a slight stenosis was noted and in 1 case a superficial insufficiency of the suture without stenosis.

Key words: Atresia, esophagus - Stenosis, anastomontic - Surgery, new technique.

Zusammenfassung. Nach Korrektur einer Oesophagusatresie vom Typ IIIb liegt die postoperative Rate der Anastomosenstenosen bei 15-40\%. Als neues Verfahren wurde seit 1974 die Zipfelplastik (nach Gütgemann u.a.) auf die Anastomosierung des Oesophagus bei Atresien dieses Typs übertragen. Vorteile: Vermeiden einer zirkulären Anastomose; Verlagern der Zugspannungskräfte in eine schräge Ebene. Ergebnisse: Von 14 Operierten überlebten 10. $8 \mathrm{mal}$ glatter Verlauf ohne Stenose, 1 mal leichte Stenose, 1 mal flüchtige Nahtinsuffizienz ohne Stenose.

Schlüsselwörter: Oesophagus-Atresie - Anastomosenstenose - Neue Operationstechnik. 